\title{
Analysis of coal dust source strength in open storage yard of coal port area of Huanghua Port
}

\author{
Dong Shipei ${ }^{1}$, Liu Bin ${ }^{1, *}$ \\ ${ }^{1}$ Laboratory of Waterway Environmental Protection Technology, Tianjin Research Institute for Water Transport Engineering, Tianjin \\ 300456, China
}

\begin{abstract}
Starting in 2017, the Ministry of Ecology and Environment began to implement a pollution permit system nationwide, in which environmental protection authorities issue permits to enterprises and institutions and supervise them in accordance with the permits. The accounting results of pollutant emissions are an important basis for the issuance of emission permits. At present, the air pollutant accounting methods for emissions from fixed emission facilities are mature and reliable, while there is no mature calculation method for coal dust emission in open storage yard. In this paper, based on the data of area, volume and coal nature of open storage yard in the coal port area of Huanghua Port, the author calculated the strong dust source under different wind speed by using the calculation formula of bulk dust amount in large ports, so as to provide technical support for the forecast study of atmospheric environmental impact in the coal port area of Huanghua Port and the calculation of total atmospheric particulate emission by the environmental management department.
\end{abstract}

\section{INTRODUCTION}

According to the China National Bureau of Statistics recently released data show that the total coal consumption of 2.7 billion tons in 2019, coal consumption accounted for $62.0 \%$ of total energy consumption, In China, coal mainly through the coalproducing areas through the railway to the port, and then transported from the port to the country's major coal consumption area. With the continuous increase of coal throughput, the coal port area and the surrounding urban air environment quality is affected. The public is increasingly concerned about the atmospheric environment, environmental management departments of air pollution emissions management increasingly stringent ${ }^{[1]}$.

At present, the way of coal storage is mainly for open Yard, the coal yard is open coal dust source, the source is strong with uncertainty, the coal in the yard and loading and unloading process ${ }^{[2]}$, the amount of dust and the amount of work, Surface area, particle size, water content and wind speed, etc ${ }^{[3]}$. The determination of coal dust source is more complex, which makes it difficult for the analysis of atmospheric environmental impact forecast and environmental management department to calculate the total emission of particulate matter. Therefore, the calculation and analysis of coal dust source in the open Yard yard of coal port area can provide reference for the setting of atmospheric environmental protection measures and environmental management of the port ${ }^{[4]}$.
Huanghua port is a regional important port along the coast of Hebei province. It is also one of the major energy export ports of China, and the coal port area of HuangHan port will reach 200 million tons by 2018 . This paper will take HuangHuan port as an example to comprehensively analyze the calculation method of coal air pollution.

The pollution source of open coal yard in Huanghua port can be divided into three types according to the characteristics of dust formation. One type is static dust formation on the surface of coal yard, the occurrence of which is related to the surface moisture content and surface wind speed of the dust source. The second type is dynamic dust emission during loading, unloading, and transportation. The number of dust emission is related to the environmental wind speed and loading and unloading height. The three types are fixed discharge facilities, the amount of which is mainly related to the type of exhaust equipment and the type of dust removal facilities.

This paper focuses on the analysis of the first and second pollution sources.

\section{CALCULATION METHOD}

\subsection{Analysis of coal characteristics}

According to the several main types of coal port coal dust particle size measurement test, of which the highest capacity and the largest fine particles content spray coal (sample 3) as a representative types of calculation under different wind speed up dust source is strong.

\footnotetext{
*Corresponding author:635803523@qq.com
} 
In the natural dry state, the surface moisture content of coal is about $3.2 \%$, easy to dust. General bulk cargo requirements of its moisture content should not be higher than $8 \%$ to $10 \%$, so sprinkler dust when the moisture content control in about $8 \%$ is appropriate ${ }^{[5]}$.

In the process of coal piling and coal extraction, a large amount of water spraying is required. In the process of water spraying, the moisture content of coal is generally higher than that of coal piling and coal extraction. In the process of water spraying, the moisture content of coal is generally higher than $10 \%$.

\subsection{Pollution source concentration calculation method}

The static dust on the surface of the coal yard, the amount of its occurrence and the surface moisture content of the dust source and the surface wind speed, The loading and unloading process of the dynamic dust, related to the occurrence quantity and operation quantity, wind speed,loading and unloading height ${ }^{[6]}$.

\subsubsection{Static dust}

The calculation method of static dust calculation is adopted in the evaluation code of " Port construction Project Environmental Impact Assessment Specification

". The calculation formula is as follows:

$$
\begin{gathered}
Q_{1}=0.5 \alpha\left(U-U_{0}\right)^{3} S \\
U_{0}=0.03 \cdot e^{0.5 w}+3.2
\end{gathered}
$$

$Q_{1} \_$amount of dust

$\alpha \_$bulk cargo type adjustment coefficient, The value of 1.0

$U$ _ average wind speed in the yard,calculate the average wind speed over the years, $5.5 \mathrm{~m} / \mathrm{s}$

$$
\begin{aligned}
& U_{0} \_ \text {starting wind speed, } \mathrm{m} / \mathrm{s} \\
& S_{\longrightarrow} \text { surface area, } \mathrm{m}^{2}
\end{aligned}
$$

The starting wind speed is about $4.84 \mathrm{~m} / \mathrm{s}$ at $8 \%$ moisture content

$w-$ moisture content, $8 \%$

Table 1. The particle size distribution of coal

\begin{tabular}{cccccccccc}
\hline $\begin{array}{c}\text { Particle } \\
\text { size } \\
(\mu \mathrm{m})\end{array}$ & $125-75$ & $75-45$ & $45-28$ & $28-10$ & $10-7.5$ & $7.5-5$ & $5-2.5$ & $<2.5$ & $\begin{array}{c}\text { cumulative } \\
\text { frequency } \\
(\%)\end{array}$ \\
\hline $\begin{array}{c}\text { median size } \\
(\mu \mathrm{m})\end{array}$ & 100 & 60 & 36.5 & 19 & 8.75 & 6.25 & 3.75 & 2.5 & \\
sample 1 & 0.73 & 0.62 & 0.34 & 0.44 & 0.09 & 0.1 & 0.11 & 0.06 & 2.49 \\
sample 2 & 2.31 & 1.88 & 1.25 & 1.68 & 0.35 & 0.43 & 0.56 & 0.40 & 8.86 \\
sample 3 & 2.97 & 3.05 & 2.77 & 4.89 & 0.97 & 1.09 & 1.22 & 0.81 & 17.77 \\
sample 4 & 5.77 & 3.55 & 1.57 & 1.82 & 0.44 & 0.60 & 0.86 & 0.57 & 15.18 \\
sample 5 & 1.45 & 1.05 & 0.66 & 1.00 & 0.21 & 0.24 & 0.29 & 0.16 & 5.06 \\
sample 6 & 2.71 & 2.27 & 1.79 & 2.90 & 0.60 & 0.71 & 0.90 & 0.74 & 12.62 \\
sample 7 & 2.24 & 1.31 & 0.83 & 1.44 & 0.35 & 0.42 & 0.49 & 0.26 & 7.34 \\
\hline
\end{tabular}

\subsubsection{Dynamic dust}

In the process of piling up and collecting materials, a pile taking machine is used to perform the operation. The above links produce dynamic dust during the operation.Dynamic dust calculation formula is adopted in the evaluation code of "Port construction Project Environmental Impact Assessment Specification". The calculation formula is as follows:

$$
\begin{aligned}
& Q_{2}=\alpha \beta H e^{\omega_{2}\left(w_{0}-w\right)} Y /\left[1+e^{0.25\left(v_{2}-U\right)}\right] \\
& Q_{2} \text { amount of dust, } \mathrm{kg} ; \\
& U_{\text {__ average wind speed in the yard, calculate the }}
\end{aligned}
$$
average wind speed over the years, $5.5 \mathrm{~m} / \mathrm{s}$;

$Y \_$amount of loading and unloading, 2 million tons。

$H \longrightarrow$ height, m;

$w$ moisture content, $\%$;

$\alpha \_$bulk cargo type adjustment coefficient, The value of 1.0

$\beta$ _ operating coefficient, the value of 1.0 ;

$\omega_{2}$ Water action coefficient, the value of
0.45 ;

$w_{0} \_$critical value of the action coefficien, the value of $6 \%$;

$v_{2}$ _t the amount of dust in the work is up to half the wind speed, the value of $16 \mathrm{~m} / \mathrm{s}^{[7]}$ 。

The stacking and reloading equipment of large specialized coal wharf generally selects the stacking machine, reloading machine or stacking and reloading machine. Combined with the characteristics of this project, the design of the yard stacking and reclaiming equipment USES the reclaiming machine for stacking, reclaiming and reclaiming operations. The rated stowing capacity of the stowing machine is $8000 \mathrm{t} / \mathrm{h}$, the stowing machine is $9 \mathrm{~m}$ track and the revolving radius is $47 \mathrm{~m}$; The rated capacity of the reclaiming machine is $8000 \mathrm{t} / \mathrm{h}$, the gauge of the reclaiming machine is $12 \mathrm{~m}$, and the revolving radius is $50 \mathrm{~m}$.

The mechanical efficiency and quantity of the open yard work are carried out in table 2 Calculate. 
Table 2. Mechanical situation table of the yard work

\begin{tabular}{ccc}
\hline $\begin{array}{c}\text { Operating } \\
\text { equipment }\end{array}$ & $\begin{array}{c}\text { Efficiency of a } \\
\text { single }\end{array}$ & $\begin{array}{c}\text { Number of } \\
\text { equipment }\end{array}$ \\
\hline stacker & $8000 \mathrm{t} / \mathrm{h}$ & 2 \\
reclaimer & $8000 \mathrm{t} / \mathrm{h}$ & 2 \\
$\begin{array}{c}\text { Coal blending } \\
\text { equipment }\end{array}$ & $4000 \mathrm{t} / \mathrm{h}$ & 2 \\
\hline
\end{tabular}

Different sizes of dusting links open Yard are shown in table 3 .

Table 3. different dust link dimensions

\begin{tabular}{ccc}
\hline Surface source & $\begin{array}{c}\text { Length of the } \\
\text { surface source } \\
(\mathrm{m})\end{array}$ & $\begin{array}{c}\text { width of the } \\
\text { surface source } \\
(\mathrm{m})\end{array}$ \\
\hline stacking 1 & 245 & 52 \\
stacking 2 & 245 & 52 \\
reclaimer 1 & 245 & 52 \\
reclaimer 2 & 245 & 52 \\
coal blending 1 & 245 & 52 \\
coal blending 2 & 245 & 52 \\
static dust & 1286 & 188 \\
\hline
\end{tabular}

\section{CALCULATION RESULTS}

According to the above calculation method and parameters, the coal dust source of the open yard under different wind speed conditions is calculated (Table 4).

According to the settlement results, under the same moisture content, the wind speed is the decisive factor for coal dust. The most obvious influence is the static dust emission in the yard. When the external wind speed is lower than $4 \mathrm{~m} / \mathrm{s}$, the coal dust emission in the yard is almost 0 , while when the wind speed is higher than $4 \mathrm{~m} / \mathrm{s}$, the coal dust emission in the yard has a significant increase trend.

Table 4 different wind speed from the strong source

\begin{tabular}{|c|c|c|c|c|}
\hline $\begin{array}{l}\text { Wind } \\
\text { speed } \\
(\mathrm{m} / \mathrm{s})\end{array}$ & $\begin{array}{c}\text { stacking 1-2 } \\
\left(\mathrm{g} / \mathrm{s} / \mathrm{m}^{2}\right)\end{array}$ & $\begin{array}{c}\text { reclaimer1- } \\
2 \\
\left(\mathrm{~g} / \mathrm{s} / \mathrm{m}^{2}\right)\end{array}$ & $\begin{array}{c}\text { coal } \\
\text { blending 1- } \\
2 \\
\left(\mathrm{~g} / \mathrm{s} / \mathrm{m}^{2}\right)\end{array}$ & $\begin{array}{c}\text { static dust } \\
\left(\mathrm{g} / \mathrm{s} / \mathrm{m}^{2}\right)\end{array}$ \\
\hline 1 & $1.31 \mathrm{E}-04$ & $1.31 \mathrm{E}-04$ & $6.51 \mathrm{E}-05$ & - \\
\hline 2 & $1.51 \mathrm{E}-04$ & $1.51 \mathrm{E}-04$ & $7.61 \mathrm{E}-05$ & - \\
\hline 3 & $1.75 \mathrm{E}-04$ & $1.75 \mathrm{E}-04$ & 8.79E-05 & - \\
\hline 4 & $2.03 \mathrm{E}-04$ & $2.03 \mathrm{E}-04$ & $1.01 \mathrm{E}-04$ & $2.00 \mathrm{E}-06$ \\
\hline 5 & $2.33 \mathrm{E}-04$ & $2.33 \mathrm{E}-04$ & $1.17 \mathrm{E}-04$ & $8.35 \mathrm{E}-06$ \\
\hline 6 & 2.69E-04 & $2.69 \mathrm{E}-04$ & $1.34 \mathrm{E}-04$ & 4.19E-07 \\
\hline 7 & $3.10 \mathrm{E}-04$ & $3.10 \mathrm{E}-04$ & $1.55 \mathrm{E}-04$ & $1.19 \mathrm{E}-08$ \\
\hline 8 & $3.56 \mathrm{E}-04$ & $3.56 \mathrm{E}-04$ & $1.78 \mathrm{E}-04$ & $2.58 \mathrm{E}-08$ \\
\hline 9 & $4.10 \mathrm{E}-04$ & $4.10 \mathrm{E}-04$ & $2.05 \mathrm{E}-04$ & $5.42 \mathrm{E}-08$ \\
\hline 10 & 4.71E-04 & 4.71E-04 & $2.35 \mathrm{E}-04$ & $5.62 \mathrm{E}-08$ \\
\hline 11 & 5.39E-04 & $5.39 \mathrm{E}-04$ & $2.70 \mathrm{E}-04$ & $2.06 \mathrm{E}-09$ \\
\hline
\end{tabular}

\section{PROTECTION MEASURES}

The main dust production link in Huanghua port is equipment and material falling dust, belt machine vibrating dust and wind dust, material piling machine, material taking machine, material piling and taking machine and train unloading, etc. The effective measures currently adopted include the following aspects:
(1) Windproof dust suppression net

In order to further control the dust generated during the operation of the storage yard, a windbreak net was set around the storage yard. The dustproof mechanism of windproof net is divided into two functions: windproof and dust-catching.

According to the Tianjin Research Institute for Water Transport Engineering for the similar coal terminal type wind screen windproof effect research and resistance coefficient of special research, preliminary determined the project of the windproof net screen for: windproof net mesh opening rate epsilon $\varepsilon=40 \%$, hole radius $R=6$ $\mathrm{mm}$ round hole, hole arrangement to stagger, windproof board Angle is $140^{\circ}$ windproof board ${ }^{[8]}$.

According to the investigation on the construction status and anti-wind effect of the anti-wind network layout height based on the domestic large-scale coal port yards and steel yards, when the height of the anti-wind network is $17 \mathrm{~m}$, the anti-wind effect can reach $80 \sim 85 \%$ after the comprehensive anti-dust measures of the antiwind network, sprinkling water and anti-dust agent are taken. After increasing the height of the windscreen, the shielding distance of the windscreen is increased, which effectively increases the dust suppression effect of the windscreen. At the same time, the comprehensive dust suppression effect of wind-proof net combined with sprinkling water is $85 \% \sim 95 \%$. The height of the windproof net designed in this project is $23 \mathrm{~m}$, and the dustproof effect can reach $90 \sim 95 \%$ after adopting the comprehensive dust-proof measures of wind-proof net, sprinkling water and dust-inhibiting agent.

Combined with the dry fog and wet dust removal measures, the storage yard and the loading and unloading operation area can achieve effective control of dust emission sources, dust removal system overall dust suppression effect can reach more than $90 \%$.

(2) Dry fog system

Due to the violent movement of materials and large dust production when the dumper turns and dumps coal, the ordinary dry dust removal system cannot completely control the diffusion of dusty airflow in such a short time. Therefore, the rolling operation time in the room air dust, dust area is also very serious. The water mist particles produced by the dry fog dust suppression system can reach less than $10 \mathrm{~m}$, and the size of the most active dust particles is similar to the collision, adsorption, condensation to form a larger dust mass, which can fall naturally under the action of gravity and will not escape with the airflow. The dust removal efficiency can reach above $96 \%$, and the dust concentration on site can be stable below $10 \mathrm{mg} / \mathrm{Nm}$ after treatment.

The dry fog dust-suppression system consists of the main engine, universal joint assembly, air-water distribution box, air compressor and automatic control system. With man-machine interface, it can feed back electrical signals such as starting up, shutting down, blocked filter, low air pressure, low water pressure, automatic/manual operation of dry fog dust-suppression device to the control room. Manual and automatic control modes can be realized.

(3) Wet dust removal 
For the stacker, reclaimer and material transfer place of stacker and reclaimer, a dust suppression system combining dry mist and sprinkling water is set. The sprinkling dust removal system is composed of sprinkling pipe, manual valve, solenoid valve, check valve, filter, flow meter, electric heating belt and thermal insulation structure, and sprinkler nozzle group. The sprinkler system is also equipped with a compressed air purge system for timely cleaning of the sprinkler system in winter.

(4) Greening projects

In the construction of the surrounding area of the coal yard, the greenbelt can reduce the diffusion of coal dust produced during the dock operation. In the production area and the auxiliary production area on both sides of the road to plant trees with high survival rate, in the greening arrangement and tree species selection should be combined with environmental protection and urban development planning as far as possible, to maintain a coordinated pattern with the surrounding environment, while not affecting the process layout and production management, to increase the greening coefficient as far as possible.

\section{CONCLUSION}

According to the strong calculation results of the coal dust source in the coal port area of Huanghua port, it can be seen that, in the case of moisture content of the same coal, the higher wind speed, the greater dust. Therefore, the outdoor yard should set up the anti-windscreen and other corresponding dustproof measures, reduce the wind speed in the open yard, and can effectively control the coal dust in the open yard.

\section{ACKNOWLEDGEMENTS}

This paper is one of the phased achievements of the National Nonprofit Institute Research Grants of Tianjin Research Institute for Study on integrated Remediation technology of Immobilized microorganisms in Polluted sea water (No. TKS190408).

\section{REFERENCES}

1. Wang Tie-li. Environmental pollution and prevention and control of coal railway transportation [J]. Clean Coal Technology,2014,20(3):112-114.

2. Su Jun-li. Analysis of the applicability of open yard and closed yard of coal terminal [J]. Port \& Waterway Engineering, 2011,457(9):154-158.

3. Cong Xiao-chun, Experimental study on force starting of dust particles[J]. China Mining Magazine, 2003,12(9):32-34.

4. Qiao Chao-qi. The application of yard coal technology in port bulk system [J]. China Harbour Engineering,2015, 35 (4):52-54
5. Wang Dan,Wang Chuan-yu,Li Zong-liang,etc. Study on the influence factors of coal yard dust [J]. Coal,2010,11(1):1-2.

6. Zhang Guang-yu,Zhan Shui-fen,Zhang Xiao-chun. Theory and technical method of pollution control of dust pollution in port [M].beijing:China Communications Press,2009:80-82.

7. Zhan Shui-fen. Experimental Research on the construction project of the anti-windscreen in HuangHua port coal mine [R].TianJin: Tianjin Research Institute for Water Transport Engineering,M.O.T,2008.

8. Zhan Shui-fen Research on key technology of windproof net construction of port bulk cargo yard [R].TianJin: Tianjin Research Institute for Water Transport Engineering,M.O.T,2009. 